\title{
The Chemical Composition of Vaccinia Virus
}

\author{
BY H. T. ZWARTOUW \\ Microbiological Research Establishment, Porton, Wiltshire
}

(Received 22 July 1963)

\begin{abstract}
SUMMARY
Samples of purified vaccinia virus chemically analysed had the following composition (\%): N, 14.7; P, 0.49; S, 0.76; DNA, 3.2; total lipid, 5.0 (including cholesterol, 1.2; phospholipid, 2.1); trace constituents detected were: RNA, 0.1 ; carbohydrate, 0.2 ; $\mathrm{Cu}, 0.02$; flavin, $5 \times 10^{-4}$; biotin, $1.3 \times 10^{-5}$. These results are compared with other published figures and the differences discussed. The trace constituents are not considered to be true components of the virus. On the other hand, there is no evidence for regarding cholesterol and the other lipid components as non-essential constituents of the virus.
\end{abstract}

\section{INTRODUCTION}

Twenty years ago Smadel \& Hoagland (1942) reviewed their extensive work on vaccinia virus, including a report on its chemical composition. This was the first detailed and comprehensive chemical analysis of an animal virus and the results are still generally quoted. Vaccinia virus had a relatively complex composition in contrast to the plant viruses, which contained only nucleic acid and protein. Thus, in addition to DNA and protein, vaccinia virus was shown to contain cholesterol, phospholipid, neutral fat, carbohydrate, copper, flavin and biotin. All these constituents were considered to be integral components of the virus, except the cholesterol which could be removed from the virus without loss of infectivity. Since this investigation, the only published quantitative results on the composition of vaccinia virus have been a report that the copper content was lower (Joklik, 1962a) and several reports on the nucleic acid content. Figures published for DNA have varied over a fourfold range (2.1-7.8 \%) but these have not been correlated with phosphorus content. However, there has been general agreement that the RNA content is very small. The present paper reports a chemical analysis of several samples of purified vaccinia virus. Some important differences have been found between these results and those of the earlier workers.

\section{METHODS}

Virus samples. Vaccinia virus was obtained from the skin of infected rabbits and purified by centrifugation in sucrose density gradients as described by Zwartouw, Westwood \& Appleyard (1962).

Virus infectivity. Virus samples were titrated on chicken embryo chorioallantoic membranes by the method of Westwood, Phipps \& Boulter (1957) and infectivity expressed as pock-forming units (p.f.u.)/ml.

Dry weight. Samples of virus were dried to constant weight at $60^{\circ}$ and $0.01 \mathrm{~mm} . \mathrm{Hg}$ over $\mathrm{P}_{2} \mathrm{O}_{5}$. All analytical results are expressed in terms of dry weight. 
Nitrogen. After Kjeldahl digestion, nitrogen was estimated with Nessler's reagent.

Phosphorus. Phosphorus was assayed as described by King (1946).

Sulphur. Samples were digested with $\mathrm{HClO}_{4}$ and assayed by the method of Spencer (1960).

Lipid. Dried virus (15-20 mg.) was extracted for $1 \mathrm{hr}$. with a boiling mixture of ethanol + ether $(3+1$, by vol.). Further extraction with the same solvent, or with a mixture of chloroform and methanol, did not remove any more lipid. The solvent was evaporated from the lipid extract and the residue of lipid extracted with light petroleum (boiling range $40-60^{\circ}$ ); this left a trace of insoluble material. The lipid obtained after evaporation of the light petroleum was dried at $20 \mathrm{~mm} . \mathrm{Hg}$ and $20^{\circ}$ and weighed as total lipid. This was dissolved in chloroform and samples were used for estimation of cholesterol by the method of Green, Lowe \& Morton (1955) and for phosphorus. Phospholipid was calculated from the lipid-P results by assuming that the phospholipid contained $4.0 \%$ P. Neutral fat was calculated by subtracting the cholesterol + phospholipid figures from the total lipid.

$D N A$. Virus samples were extracted with $0.5 \mathrm{~N}-\mathrm{HClO}_{4}$ at $90^{\circ}$ for $20 \mathrm{~min}$. These conditions produced the maximum DNA in solution obtainable by a single acid extraction. A second similar extract contained about $5 \%$ of the amount of DNA in the first and further extracts did not contain detectable amounts of DNA. Routinely, DNA was measured in two successive hot acid extracts by the diphenylamine reaction as modified by Burton (1956). A standard solution of calf thymus DNA was adjusted by $\mathbf{P}$ content to correspond to the theoretical value $(10.04 \% \mathrm{P})$ for a DNA tetranucleotide and heated in $0.5 \mathrm{~N}-\mathrm{HClO}_{4}$ in the same manner as the virus samples.

$R N A$. To facilitate the measurement of small amounts of RNA in virus material which contained much larger amounts of DNA, the nucleic acids were separated by a modification of the method of Schmidt \& Thannhauser (1945). Virus was suspended in $0.3 \mathrm{~N}-\mathrm{KOH}$ and maintained at $37^{\circ}$ for $16 \mathrm{hr}$. After acidification with $\mathrm{HClO}_{4}$, the hydrolysed RNA in solution was assayed by the ribose method of Bolognani, Coppi \& Zambotti (1961). A standard solution of yeast RNA was adjusted by $\mathbf{P}$ content to correspond to the theoretical value $(9.5 \% \mathbf{P})$ for an RNA tetranucleotide.

Copper. Virus samples were digested with a mixture of sulphuric and nitric acids, diluted with water, boiled to hydrolyse any pyrophosphate, neutralized and the copper present determined by the method of Kolthoff \& Sandell (1952).

Flavin. 'Free' and 'combined' flavin was assayed by the method of Bessey, Lowry \& Love (1949) and expressed as riboflavin by using a riboflavin standard.

Biotin. Virus samples were refluxed with $4 \mathrm{~N}-\mathrm{H}_{2} \mathrm{SO}_{4}$ for 30 min. and biotin assayed by the procedure of Wright \& Skeggs (1944).

Carbohydrate. The quantitative Molisch reaction as described by Kabat \& Mayer (1948) was used.

\section{RESULTS}

\section{Principal components}

The analytical values for the principal components of six samples of purified vaccinia virus are shown in Table 1 . They agree well with the results of Smadel \& Hoagland (1942) except for the DNA content. 
$D N A$. Since our value for the DNA content (3.2\%) was considerably lower than the original figure (5.6\%) of Hoagland, Lavin, Smadel \& Rivers (1940), we tested three other methods of extracting the DNA for assay. (1) Virus was treated successively with cold $\mathrm{HClO}_{4}$, solvent (ethanol +ether), $0.3 \mathrm{~N}-\mathrm{KOH}$ at $37^{\circ}$ and finally $0.5 \mathrm{~N}-\mathrm{HClO}_{4}$ at $90^{\circ}$ as in the modified Schmidt-Thannhauser method. (2) Virus was partially digested with pepsin, dissolved in hot alkali and the precipitate obtained with acetic acid and methanol assayed for DNA. This was the original procedure of Hoagland, Lavin et al. (1940). (3) Virus was dissolved in hot alkali and assayed directly as described by Joklik (1962a). None of these procedures gave higher values for the DNA content.

Table 1. Chemical analysis of vaccinia virus samples

\begin{tabular}{|c|c|c|c|c|c|c|c|}
\hline \multirow{2}{*}{$\begin{array}{l}\text { Virus } \\
\text { sample }\end{array}$} & \multicolumn{7}{|c|}{$\%$ of dry weight } \\
\hline & $\mathbf{N}$ & $\mathbf{P}$ & $\mathbf{S}$ & DNA & Total lipid & Cholesterol & Phospholipid \\
\hline 1 & $14 \cdot 8$ & 0.51 & $0 \cdot 73$ & $\mathbf{3} \cdot \mathbf{3}$ & 4.5 & 0.7 & 1.9 \\
\hline 2 & $14 \cdot 2$ & $0 \cdot 55$ & 0.93 & $\mathbf{3} \cdot \mathbf{0}$ & $4 \cdot 1$ & $1 \cdot 5$ & $1 \cdot 6$ \\
\hline $\mathbf{3}$ & $15 \cdot 0$ & 0.50 & $0 \cdot 71$ & $\mathbf{3} \cdot \mathbf{0}$ & $7 \cdot 2$ & $1 \cdot 6$ & $3 \cdot 4$ \\
\hline 4 & $14 \cdot 3$ & 0.50 & 0.72 & $3 \cdot 1$ & 4.5 & $1 \cdot 1$ & 1.7 \\
\hline 5 & $14 \cdot 9$ & 0.51 & $0 \cdot 77$ & $\mathbf{3} \cdot \mathbf{3}$ & $4 \cdot 8$ & $1 \cdot 2$ & $1 \cdot 9$ \\
\hline 6 & 14.9 & 0.56 & $0 \cdot 70$ & $\mathbf{3} \cdot \mathbf{3}$ & $5 \cdot 1$ & $\mathbf{1 \cdot 2}$ & $\mathbf{2} \cdot \mathbf{1}$ \\
\hline Mean value & 14.7 & 0.52 & $0 \cdot 76$ & $\mathbf{3 \cdot 2}$ & $5 \cdot 0$ & $1 \cdot 2$ & $2 \cdot 1$ \\
\hline
\end{tabular}

Table 2. Infectivity of dried and solvent-extracted vaccinia virus

\begin{tabular}{|c|c|c|}
\hline \multirow[b]{2}{*}{ Virus sample } & \multicolumn{2}{|c|}{ Infectivity* } \\
\hline & p.f.u. $\uparrow / \mathrm{ml}$. & $\%$ of untreated \\
\hline Untreated & $6.9 \times 10^{9}$ & 100 \\
\hline Freeze dried & $5 \cdot 6 \times 10^{8}$ & 8 \\
\hline $\begin{array}{l}\text { Freeze dried and extracted with } \\
\text { ether } 4 \mathrm{hr} \text {. at }-10^{\circ}\end{array}$ & $3.4 \times 10^{7}$ & 0.5 \\
\hline $\begin{array}{l}\text { Freeze dried and extracted with } \\
\text { ethanol + ether }(3+1 \text { by vol. }) \\
4 \mathrm{hr} \text {. at }-10^{\circ}\end{array}$ & $2.7 \times 10^{6}$ & 0.04 \\
\hline
\end{tabular}

Lipid. Experiments were done to determine whether the removal of lipid from the virus was accompanied by loss of infectivity. The lipid content of the virus was not decreased after attempting further purification by centrifugation in sucrose density gradients. Virus suspended in $5 \%$ Brij 35 (polyoxyethylene lauryl ether) and agitated by ultrasonic vibration for $30 \mathrm{~min}$. lost $50 \%$ of its original lipid (cholesterol, phospholipid and neutral fat were all lost in about the same proportion) but suffered a greater loss $(84 \%)$ of its infectivity.

A concentrated aqueous suspension of virus was added to 100 volumes of acetone at $-60^{\circ}$. The virus was recovered and washed with acetone by centrifugation at $-20^{\circ}$ before resuspension in dilute buffer. This cold acetone-extracted virus had only $0.003 \%$ of the original infectivity. Evaporation of the acetone and extraction of the residue with light petroleum showed that, within the limits of measurement, 
all the lipid had been removed from the virus. A similar result was obtained by using a mixture of ethanol + ether in place of acetone.

In an experiment similar to that of Hoagland, Smadel \& Rivers (1940), freeze-dried virus was extracted with ether or ethanol + ether mixture. Ethanol + ether caused a considerable loss of infectivity and although ether alone had less effect, it nevertheless caused a 16-fold decrease in infeetivity (Table 2). This is contrary to the results the earlier workers found after ether extraction.

Vaccinia virus has been classified as 'ether-stable' by Andrewes \& Horstmann (1949). Using their conditions, i.e. adding ether and $10 \%$ serum to an aqueous virus suspension and leaving the mixture at $4^{\circ}$, we confirmed that no infectivity was lost in $24 \mathrm{hr}$. However, when virus suspended in dilute buffer was incubated with ether at $37^{\circ}$, infectivity rapidly decreased (1000-fold in $4 \mathrm{hr}$ ) while the infectivity of incubated controls without ether did not. In general, all our experiments showed that vaccinia virus lost infectivity when in contact with fat solvents.

\section{Trace substances}

$R N A$. Samples of purified virus consistently contained $0 \cdot 3-0.5 \% \mathrm{RNA}$. This was most easily measured after separation from DNA by alkaline hydrolysis (see Methods). Attempts to eliminate the RNA by repeating the purification procedure (centrifugation in sucrose density gradients) resulted in a decrease of the RNA content to $0 \cdot 2-0 \cdot 3 \%$. To facilitate this re-purification, the virus was first incubated with $0.0001 \%$ trypsin in $0.01 \mathrm{M}$-phosphate (at $\mathrm{pH} 8$ ) at $37^{\circ}$; this decreased aggregation of the particles without diminishing infectivity.

However, the RNA content was decreased more effectively by treatment with ribonuclease. Samples of virus ( $1 \mathrm{mg} . / \mathrm{ml}$.) were incubated at $37^{\circ}$ for $1 \mathrm{hr}$. in $0.01 \mathrm{M}$ phosphate and 0.005 $\mathrm{m}$-ethylenediaminetetraacetic acid (EDTA) at $\mathrm{pH} 7 \cdot 6$ with $0.1 \mathrm{mg}$. ribonuclease $/ \mathrm{ml}$. After washing in the centrifuge, the recovered virus had suffered no loss of infectivity and contained only $0 \cdot 1 \%$ RNA. Further treatment with ribonuclease did not diminish the RNA content below $0.1 \%$.

Copper. The copper content of different virus samples varied over a fourfold range $(0.009-0.035 \%)$, with a mean content of $0.021 \%$. Crude virus obtained as skin scrapings from infected rabbits contained only $0.0003 \%$ copper. The copper content of purified virus was not decreased by suspending the virus in 0.005 M-EDTA at $\mathrm{pH} 7 \cdot 5$ for $1 \mathrm{hr}$ at $37^{\circ}$.

When virus was suspended $(1 \mathrm{mg} . / \mathrm{ml}$.) in a solution of copper sulphate $(0 \cdot 1 \mathrm{mg}$. copper $/ \mathrm{ml}$.) at $37^{\circ}$ for $1 \mathrm{hr}$ and subsequently recovered and washed three times by centrifugation, the copper content of the virus had increased 20-fold. Although this increased copper content was not diminished by washing the virus with water, two-thirds of it was removed by treatment with $0.05 \mathrm{~m}$-EDTA at $\mathrm{pH} \mathrm{7 \cdot 5}$. The remaining one-third (equal to 8 times the original copper content of the virus) was not removed by repeated treatment with EDTA (Table 3). These experiments showed that copper was readily adsorbed by vaccinia virus and was not easily removed.

Spectroscopic examination of purified virus detected only one other metal, namely calcium; its amount varied widely, from less than $0.02 \%$ to about $0.1 \%$.

Flavin. Small quantities of flavin were present (3-7 $\mu \mathrm{g} . / \mathrm{g}$. , expressed as riboflavin); $90 \%$ of this was in a conjugated form (i.e. liberated after acid hydrolysis). 
Crude virus before purification contained $8 \mu \mathrm{g}$. flavin/g., $25 \%$ of which was in a conjugated form.

Biotin. Different samples of purified virus contained between 0.06 and $0.21 \mu \mathrm{g}$. biotin/g., with a mean content of $0.13 \mu \mathrm{g} . / \mathrm{g}$. Crude virus contained $0.25 \mu \mathrm{g} . / \mathrm{g}$.

Carbohydrate. The Molisch reaction, after allowing for the measured RNA content of the samples, indicated that purified virus samples contained $0 \cdot 1-0 \cdot 3 \%$ carbohydrate expressed as glucose.

Table 3. Adsorption and attempted removal of copper from vaccinia virus

Virus
sample
1
2

3
4
5

\begin{tabular}{ll}
\multicolumn{1}{c}{ Treatment of sample } & $\begin{array}{c}\text { Copper conten } \\
(\%)\end{array}$ \\
Untreated & $0 \cdot 022$ \\
$\mathrm{Cu}^{2+}$ solution then washed three times & $0 \cdot 47$ \\
with water & \\
Sample 2 after one EDTA treatment & $0 \cdot 17$ \\
Sample 2 after two EDTA treatments & $0 \cdot 15$ \\
Sample 2 after three EDTA treatments & $0 \cdot 18$
\end{tabular}

Table 4. Phosphorus distribution in vaccinia virus

\begin{tabular}{|c|c|c|}
\hline & \multicolumn{2}{|c|}{$\%$ of total phosphorus } \\
\hline Phosphorus fraction of virus & Uncorrected & $\begin{array}{l}\text { Corrected for RNA } \\
\text { removable by } \\
\text { ribonuclease* }\end{array}$ \\
\hline Calculated from DNA content & 61 & 65 \\
\hline Lipid phosphorus & 16 & 17 \\
\hline Cold acid soluble & $\mathbf{3}$ & 3 \\
\hline $\begin{array}{l}\text { Liberated by warm alkali and not present } \\
\text { as nucleic acid }\end{array}$ & 8 & 9 \\
\hline Not extracted by hot acid or warm alkali & 5 & 5 \\
\hline Calculated from RNA content & 8 & 2 \\
\hline
\end{tabular}

\section{Phosphorus distribution in vaccinia virus}

The mean analytical figures for DNA, phospholipid and RNA (without ribonuclease treatment) accounted for 61,16 and $8 \%$, respectively, of the total phosphorus found in the virus. Experiments were done to determine the nature of the remaining $15 \%$. Cold acid $\left(0.5 \mathrm{~N}-\mathrm{HClO}_{4}\right.$ at $\left.0^{\circ}\right)$ extracted $3 \%$ of the total $\mathrm{P}$ from the virus. In the Schmidt-Thannhauser extraction, the RNA fraction (i.e. material which was acid-soluble after alkaline hydrolysis) always contained more phosphorus than was accounted for by its nucleic acid content. 'This extra phosphorus, which was not present as hydrolysed RNA or DNA, amounted to $8 \%$ of the total P. The same figure for alkali-labile $P$ was obtained in another way. Virus was serially extracted with cold acid, ethanol + ether and finally hot $0.5 \mathrm{~N}-\mathrm{HClO}_{4}$ thus removing successively acid-soluble $P$, lipid $P$ and nucleic acid $P$ (RNA and DNA). The residue, which contained $13 \%$ of the total $\mathrm{P}$, was then hydrolysed in $0.3 \mathrm{~N}-\mathrm{KOH}$ for $16 \mathrm{hr}$ at $37^{\circ}$ and separated again into acid-soluble and insoluble fractions. These contained 8 and $5 \%$ of the total $\mathbf{P}$, respectively. Table 4 shows that all of the phosphorus was accounted for in the different components. After correction for the RNA removable 
by ribonuclease treatment, the results suggest that $14 \%$ of the total $P$ was present as phosphoprotein, of which $9 \%$ was liberated by warm alkali and $5 \%$ was resistant to such hydrolysis.

\section{DISCUSSION}

Table 5 compares our summary of vaccinia virus composition with the results of Smadel \& Hoagland (1942). Agreement between the two sets of figures for nitrogen content and for the lipid components is very close. The earlier workers considered that the cholesterol found was not an integral part of the virus since they claimed that it could be extracted by ether with almost no loss of infectivity. We were not able to confirm this and we therefore consider that cholesterol must be regarded as a component of the virus in the same way as phospholipid and neutral fat. Although vaccinia virus has been referred to as 'ether-stable', it should be noted that the term is only relative and that the virus is sensitive to ether when the test conditions are suitably adjusted.

Table 5. Comparison of analytical values for vaccinia virus

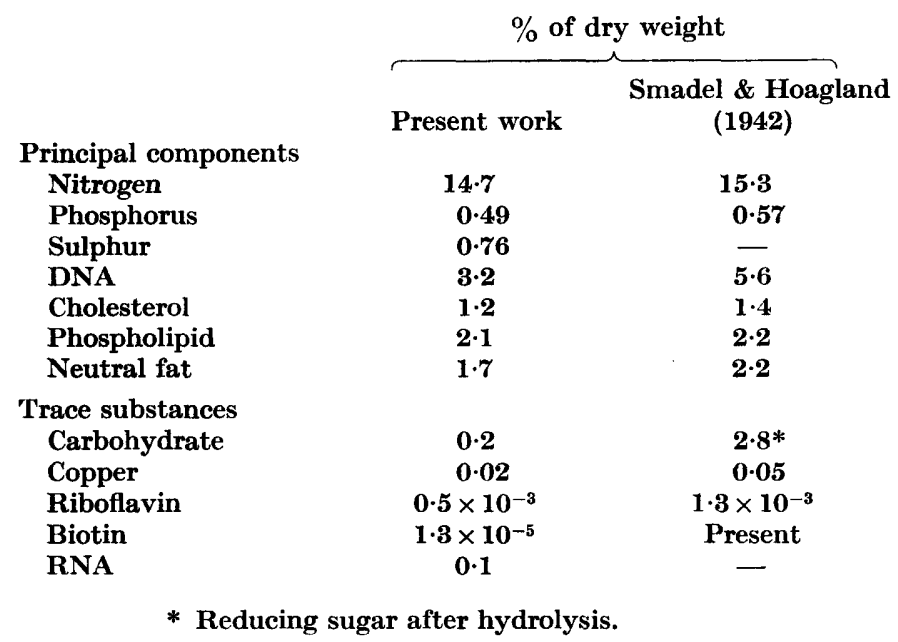

The constituents carbohydrate, copper, flavin and biotin, which were found in the earlier work, have also been detected in our virus preparations. However, the amounts of these constituents were considerably less than those claimed earlier (Table 5). The small positive carbohydrate reaction might have been due to the large amount of non-carbohydrate material necessarily present in the carbohydrate assay.

The mean result for the copper content $(0.02 \%)$ agrees closely with the figure of $0.015 \%$ reported by Joklik (1962a). We have confirmed the claim that copper is concentrated in the virus fraction during purification (Hoagland, Ward, Smadel \& Rivers, 1941) and have found additional evidence (treatment with EDTA) that the copper could not be removed from the virus. However the copper content we found was lower than that originally claimed and our figures show variation over a fourfold range. It seemed most likely that copper was strongly adsorbed by some component of the virus and that the amount found in purified virus samples varied because 
different amounts or concentrations of copper were available for adsorption in the crude virus preparations. In support of this argument we found that copper was adsorbed from solution by vaccinia virus, and adsorbed copper was not removed by washing with water, although part of it was removed by EDTA. Even after repeated treatment with EDTA, the treated virus contained a relatively large amount of adsorbed copper.

Flavin did not appear to concentrate in the virus during purification and the small amount detected is almost certainly of doubtful significance. Biotin was detected in vaccinia virus by Hoagland, Ward, Smadel \& Rivers (1940) and although they reported no quantitative results they claimed the amount present was comparable to other biotin-rich materials, such as egg yolk and liver. The amount of biotin present in our purified virus samples, which was smaller than the amount detected in crude virus, was less than one-twentieth the biotin content of liver. Thus there is no reason to regard the trace of biotin found in the virus as anything but impurity.

Table 6. Analytical values for nucleic acid in vaccinia virus

\begin{tabular}{lcc}
\multicolumn{1}{c}{ Reference } & DNA (\%) & RNA (\%) \\
Hoagland et al. (1940) & $5 \cdot 6$ & - \\
Wyatt \& Cohen (1953) & $2 \cdot 1$ & - \\
Planterose et al. (1962) & - & $0 \cdot 1$ to $0 \cdot 2$ \\
Joklik (1962a, b) & $5 \cdot 25^{*}$ & $(0 \cdot 1) \dagger$ \\
Allison \& Burke (1962) & $\mathbf{7 \cdot 8}$ & $<0 \cdot 26 \ddagger$ \\
Present work & $3 \cdot 2$ & $0 \cdot 1$
\end{tabular}

* Calculated as \% from reported $5 \cdot 8$ parts DNA/100 parts protein and allowing for $5 \%$ lipid content.

$\dagger$ Quoted for rabbit-pox virus as a maximum of $2.5 \%$ of DNA content.

$\ddagger$ Quoted as $<1 / 30$ of DNA content.

The only vaccinia virus component which has received much attention is the nucleic acid. Several values have been published for the DNA content together with attempts to demonstrate the absence of RNA. These results are compared in Table 6. In general the values for DNA are higher than our results, but there are possible explanations for this since some results are only indirectly related to the virus dry weight. The highest reported value (7.8\%) was calculated by Allison \& Burke (1962) from the measured DNA content per virus particle and the particle weight was considered to be $3 \cdot 6 \times 10^{-15} \mathrm{~g}$. Our preliminary measurements indicate that this value is too low for the particle weight. Joklik (1962 $a$ ) reported 5.8 parts of DNA in relation to 100 parts of vaccinia virus protein, the latter being measured by the colour reaction of Lowry, Rosebrough, Farr \& Randall (1951). It is arbitrary to assume that equal weights of the relatively insoluble vaccinia virus protein and an unrelated protein standard produce equal colours in the protein assay. From measurements of the distribution of ${ }^{32} \mathrm{P}$ in fractions from labelled rabbit-pox virus, after removing various impurities containing ${ }^{32} \mathrm{P}$ by cold acid and enzyme treatments, Joklik $(1962 b)$ concluded that $70 \%$ of the label represented DNA. This figure together with his result for DNA content of rabbit-pox virus (5.4 parts of DNA/100 parts protein; Joklik, $1962 a$ ) requires the virus to contain at least $0.7 \%$ total-P. This is significantly higher than the total-P found in the closely related vaccinia virus. In the earliest chemical investigations, Hoagland, Lavin, Smadel \& 
Rivers (1940) reported 5.6\% DNA and Hoagland, Smadel \& Rivers (1940) 0.57\% total-P in vaccinia virus. Smadel, Rivers \& Hoagland (1942) extracted a 'nucleoprotein antigen' from vaccinia virus with sodium hydroxide solution. This material was equal to about half the weight of the original virus and was reported to contain $6 \% \mathrm{DNA}$ and $1.8 \% \mathrm{P}$. If sodium hydroxide solution extracted all the nucleic acid from the virus, the original virus should have contained about $3 \%$ DNA and $0.9 \% \mathbf{P}$.

The colorimetric estimation of DNA, which has been used by all the investigators, depends on comparison with a DNA standard. Previous authors have not indicated whether they had made allowance for the water and metal cations in their standard DNA. Phosphorus content is the most reliable basis for preparing the standard solution and usually indicates a 25-30\% correction by weight. In view of the possible errors just discussed, we consider that our result of $3.2 \%$ DNA in vaccinia virus is the most accurate value so far reported.

The important question whether DNA is the only nucleic acid present has only been partly answered. The lowest figures for RNA quoted by various authors show that the amount is not more than $0 \cdot 1 \%$. This low figure has usually been obtained only after ribonuclease treatment of the virus. Direct measurement of this small quantity of RNA is difficult and uncertain because of interference by the $99.9 \%$ of other material. Application of the Schmidt-Thannhauser method to vaccinia virus produced a hydrolysed RNA fraction in which ribose could be assayed, but it contained phosphorus in excess of one equivalent for the ribose and had a large nonspecific ultraviolet absorption. Thus the ribose assay for RNA could not be confirmed by phosphorus analysis or by absorption at $260 \mathrm{~m} \mu$. Joklik (1962b) and Planterose, Nishimura \& Salzman (1962) have devised ingenious experiments with radioactive tracers but do not appear to have obtained any greater accuracy, and their results depend on the assumption that different viral components are uniformly labelled. Although the remote possibility must be recognized that vaccinia virus contains a small RNA component, it seems reasonable to conclude that RNA is not an essential part of the virus.

The author wishes to thank Mr D. J. Algar for valuable technical assistance.

\section{REFERENCES}

Allison, A. C. \& Burke, D. C. (1962). The nucleic acid contents of viruses. J. gen. Microbiol. 27, 181.

Andrewes, C. H. \& Horstmann, D. M. (1949). The susceptibility of viruses to ethyl ether. J. gen. Microbiol. 3, 290.

Bessey, O. A., Lowry, O. H. \& Love, R. H. (1949). The fluorimetric measurement of the nucleotides of riboflavin and their concentration in tissues. J. biol. Chem. 180, 755.

Bolognani, L., Coppi, G. \& Zambotti, V. (1961). Determination of pentoses. Experientia, $17,67$.

Burton, K. (1956). A study of the conditions and mechanism of the diphenylamine reaction for the colorimetric estimation of deoxyribonucleic acid. Biochem. J. 62, 315.

Green, B., Lowe, J. S. \& Morion, R. A. (1955). The effect of vitamin A deficiency on the cholesterol levels of the plasma and liver of the rat. Biochem. J. 61, 447.

Hoagland, C. L., Lavin, G. I., Smadel, J. E. \& Rivers, T. M. (1940). Constituents of elementary bodies of vaccinia. II. Properties of nucleic acid obtained from vaccine virus. J. exp. Med. 72, 139. 
Hoagland, C. L., Smadel, J. E. \& Rivers, T. M. (1940). Constituents of elementary bodies of vaccinia. I. Certain basic analyses and observations on lipid components of the virus. J. exp. Med. 71, 737.

Hoagland, C. L., Ward, S. M., Smadel, J. E. \& Rivers, T. M. (1940). Biotin in elementary bodies of vaccinia. Proc. Soc. exp. Biol., N.Y. 45, 669.

Hoagland, C. L., Ward, S. M., Smadel, J. E. \& Rivers, T. M. (1941). Constituents of elementary bodies of vaccinia. IV. Demonstration of copper in the purified virus. J. exp. Med. 74, 69.

JokıI, W. K. (1962a). The purification of four strains of poxvirus. Virology, $18,9$.

JokıIK, W. K. (1962b). The preparation and characteristics of highly purified radioactively labelled poxvirus. Biochim. biophys. Acta, 61, 290.

KabaT, E. A. \& MAYER, M. M. (1948). Experimental Immunochemistry, 1st ed., p. 315. Springfield, Illinois: Charles C. Thomas.

KING, E. J. (1946). Microanalysis in Medical Biochemistry, 1st ed., p. 51. London: Churchill.

KolthofF, I. M. \& SANDELL, E. B. (1952). Textbook of Quantitative Inorganic Analysis, 3rd ed., p. 637. New York: Macmillan.

Lowry, O. H., Rosebrough, N. J., FArr, A. L. \& Randall, R. J. (1951). Protein measurement with the Folin phenol reagent. J. biol. Chem. 193, 265.

Planterose, D. N., Nishimura, C. \& Salzman, N. P. (1962). The purification of vaccinia virus from cell cultures. Virology, 18, 294 .

Schmid, G. \& Thannhauser, S. J. (1945). A method for the determination of desoxyribonucleic acid, ribonucleic acid and phosphoproteins in animal tissues. J. biol. Chem. $161,83$.

Smadel, J. E. \& Hoagland, C. L. (1942). Elementary bodies of vaccinia. Bact. Rev. $6,79$.

Smadel, J. E., Rivers, T. M. \& Hoagland, C. L. (1942). Nucleoprotein antigen of vaccine virus. I. A new antigen obtained from elementary bodies of vaccinia. Arch. Path. 34, 275.

SpEnCER, B. (1960). The ultramicro determination of inorganic sulphur. Biochem. J. 75, 435.

Westwood, J. C. N., Phipps, P. H. \& Boulter, E. A. (1957). The titration of vaccinia virus on the chorioallantoic membrane of the developing chick embryo. J. Hyg., Camb. $55,123$.

Wright, L. D. \& Skeggs, H. R. (1944). Determination of biotin with Lactobacillus arabinosus. Proc. Soc. exp. Biol., N.Y. 56, 95.

WyatT, G. R. \& Conen, S. S. (1953). The bases of the nucleic acids of some bacterial and animal viruses: The occurrence of 5-hydroxymethyl-cytosine. Biochem. J. 55, 774.

Zwartouw, H. T., Westwood, J. C. N. \& Appleyard, G. (1962). Purification of poxviruses by density gradient centrifugation. J. gen. Microbiol. 29, 523. 